DOI: $10.17516 / 1997-1370-0783$

УДК 330.15

\title{
Kuzbass Economy and Carbon Control Tools
}

\author{
Galina E. Mekush* and AndreyA.Panov \\ Kemerovo State University \\ Kemerovo, Russian Federation
}

Received 24.05.2021, received in revised form 15.06.2021, accepted 29.06.2021

\begin{abstract}
Kuzbass is a resource-type region. Therefore, any prospective carbon control law is a very relevant issue for this part of Siberia. Carbon control laws aim at meeting the environmental standards set up by the Paris Agreement. For Kuzbass, carbon control means production restrictions and poor competitiveness. The research objective was to assess the potential of Kuzbass economy for the period of climate adaptation. The authors analyze various performance evaluation methods that are used to assess carbon control tools, as well as various scenarios for the development of Russian economy. The analysis shows that Kuzbass demonstrates no orientation towards structural and technological modernization, thus proving unready for the transition to low-carbon economy. Local ecosystems are able to absorb no more than $13 \%$ of greenhouse gas (GHG) emissions, while the economic indicators of the carbon intensity keep decreasing as the growth rates of the gross regional product (GRP) outstrip the consumption of fuel and energy resources. Local decision-makers can be recommended to pay special attention to the implementation rate of the best available technologies, as well as to the replication of the experience of effective climate strategies, including the sector of land use, land use change, and forestry (LULUCF). Carbon polygons and carbon farms can be a promising tool for the development of LULUCF sector, as they will also be able to increase the competitiveness of local companies on the carbon market.
\end{abstract}

Keywords: carbon control tools, Kuzbass economy, low-carbon development scenarios, carbon intensity of the economy, carbon farms

Research area: economics.

Citation: Mekush G.E., Panov A.A. (2021). Kuzbass economy and carbon control tools. J. Sib. Fed. Univ. Humanit. Soc. Sci., 14(7), 1039-1046. DOI: 10.17516/1997-1370-0783.

(C) Siberian Federal University. All rights reserved

* Corresponding author E-mail address: mekush_ge@mail.ru 


\title{
Экономика Кузбасса
}

\section{и механизмы углеродного регулирования}

\author{
Г.Е. Мекуш, А.А. Панов \\ Кемеровский государственный университет \\ Российская Федерация, Кемерово
}

\begin{abstract}
Аннотация. Перспектива внедрения в России системы углеродного регулирования для достижения экологической цели Парижского соглашения очень актуальна для регионов ресурсного типа с точки зрения возможных ограничений и снижения конкурентоспособности производимой продукции. Цель работы состоит в том, чтобы на основе анализа методических подходов по оценке эффективности различных механизмов углеродного регулирования и сценариев развития экономики России оценить потенциальные возможности экономики Кузбасса в период климатической адаптации. Выявлено, что экономика Кузбасса слабо ориентирована на структурно-технологическую модернизацию для перехода к низкоуглеродному развитию. Экосистемы на территории Кузбасса обладают потенциалом поглощения выбросов парниковых газов не более 13 \%. Показатели углеродоемкости экономики снижаются в основном за счет опережающей динамики темпов роста ВРП над потреблением топливно-энергетических ресурсов. Для лиц, принимающих решение на уровне региона, рекомендовано особое внимание уделить темпам внедрения наилучших доступных технологий, тиражирование опыта эффективных климатических стратегий компаний, в том числе в секторе ЗИЗЛХ. Предложено в качестве перспективных технологий в секторе ЗИЗЛХ, а также возможности участия компаний в рынке углеродных единиц использовать создание карбоновых полигонов и ферм.
\end{abstract}

Ключевые слова: механизмы углеродного регулирования, экономика Кузбасса, сценарии низкоуглеродного развития, углеродоемкость экономики, карбоновые фермы.

Научная специальность: 08.00.05 - экономика и управление народным хозяйством.

\section{Problem Statement}

The global socio-economic system depends on numerous crises that have a largescale impact on all spheres of human activity and hinder sustainable development. The list of global environmental problems includes climate change, marine pollution, extinction, etc. Gradually, these issues have become priority trends in the development of mankind. Nowadays, countries of the world are becoming more active in setting strategic environmental goals and proposing tools for their achievement, and Russia is not an exception. Business participates in this process, along with governments and society, as is often stated in Annual Reports of the
Davos Forum (Bobylev, 2020; Global Risk Report, 2020).

Climate change is one of the key global challenges that require united efforts of all mankind to neutralize negative environmental consequences. In 2015, the Paris Agreement on climate change replaced the Kyoto Protocol. It defined new tools of climate control that can reduce greenhouse gas (GHG) emissions. The Paris Agreement measured the level of GHG emissions as the amount of net emissions, taking into account the absorbing capacity of natural and artificial ecosystems. The goal of the Agreement is to limit global warming to well below $2{ }^{\circ} \mathrm{C}$, preferably to $1.5^{\circ} \mathrm{C}$, compared to 1990 (Paris Agreement, 2015). 
According to the Paris Agreement, the countries that signed it must lower their GHG emissions and adopt new strategic documents that will allow them to start low-carbon development based on their socio-economic interests. More than 150 countries have already submitted their own Nationally Determined Contributions, i. e. roadmaps to emissions reduction (UNFCCC, 2017). According to the roadmap developed by Russia through 2030, its greenhouse emissions are not to exceed $70 \%$ of 1990 , if the maximal absorbing capacity of forests allows it (Decree of the President of the Russian Federation No. 666, 2020; Decree of the President of the Russian Federation No. 76, 2021). For instance, the current carbon intensity of domestic electricity, including heat-and-power supply, is already $15 \%$ lower than the world average (Kulapin, 2019). Still, the Paris Agreement implies a decrease in greenhouse emissions by more than four times by 2050 (IPCC Special Report, 2018). However small, these commitments might one day limit Russia's socio-economic development, considering its high level of carbon intensity and low rates of industrial modernization. Therefore, national climate policy should pay special attention to climate control and carbon neutrality.

Russia is currently busy developing its national climate policy and carbon control tools to be used during the period of climate adaptation. The concept and methods for monitoring GHG emissions have already been formed both at the level of regions and at the level of individual businesses (Order No. 15, 2015; Order No. 300, 2015; Order No. 330, 2017). The draft Federal Law «On limiting greenhouse gas emissions» determines legal relations in the sphere of greenhouse emissions, defines the concept of climate projects and carbon units, and explains the rights and duties of members of the climate adaptation process (Draft Law, 2021).

\section{Theoretical Foundations}

In Russia, the development and implementation of carbon control tools follows two paths. The first approach is based on the introduction of greenhouse taxes and a system of emissions trading. The second focuses mostly on building economic development scenarios based on carbon intensity reduction. The process involves not only government bodies and expert community, but also businesses. Foreign experience in the application of various carbon control schemes plays an important role in developing the domestic roadmap to carbon neutrality. It includes both the experience of developed and developing countries, which are actively joining the international climate agenda. The efficiency of carbon control schemes differs from country to country (World Bank, 2016). For instance, Kazakhstan has accumulated some negative experience in emissions trading and is currently trying to improve this system (ICAP, 2018).

According to the experts of the University of the Higher School of Economics (Moscow), any potential carbon control system in Russia will depend on the following factors: high volatility of economic growth, high corruption risks, low performance of governmental institutions, and total dependence on fossil fuels. In spite of the low energy prices, oil and gas make up almost $40 \%$ of the budget revenues and more than $40 \%$ of the Russian exports, which is the highest values among all countries that practise carbon control. However, Russia will easily achieve the desired $70-75 \%$ of the 1990-level GHG emissions by 2030 because, in fact, the goal has already been achieved, and the risks can increase only if this goal is changed (Makarov, Stepanov, 2017).

The team of experts from the Institute for National Economy Forecasting of the Russian Academy of Sciences (Porfiriev et al., 2020) came to the same conclusions about the main factors that are bound to affect the potential carbon control system, should Russia adopt one. However, they predict that by 2024 the rate of economic growth may reach 3-3.5\% precisely due to the factor of production modernization. They also warn of possible economic risks from narrowing the goals of the climate agenda and underestimating the importance of switching to the best available technologies and real structural changes. It is these factors that make the climate policy of developed countries effective. 
The risk lies not so much in the increasing GHG emissions as in the slow rate of structural and technological economic modernization, as well as in the fact that the absorptive capacity of ecosystems grows due to various climate projects (Porfirev et al., 2020a). Should carbon control tools be introduced, the main risk for the Russian economy will be the poor export competitiveness in world markets as a result of non-tariff restrictions, e. g. the cross-border carbon tax that EU countries plan to introduce in $2022^{1}$ (Porfirev, 2020).

The Institute for Natural Monopolies Issues published an analytical report on the efficiency of the Kyoto Protocol. The experts assessed the risks that might follow, should Russia introduce a carbon control system according to the recommendations of the Paris Agreement. The experts are more pessimistic about the prospects for carbon control, which is bound to limit the development of the Russian economy and, first of all, its fuel and energy complex. However, they specify the need to modernize production and increase the role of LULUCF in increasing the absorptive capacity of ecosystems.

The climate control objectives will have to be lowered lest they should never be achieved. Otherwise, direct payments for GHG emissions will produce little or no economic and environmental effect (IPEM. Analytical report, 2016). This is the way Russia is now going. The current legislation on limiting GHG emissions provides for «soft» regulation by introducing a reporting system and encouraging nature users to benefit from the implementation of climate projects.

\section{Problem Statement}

The future national low-carbon agenda will depend on the specifics of regions, namely their economy and readiness for climate adaptation. The present study evaluates the readiness of the Kemerovo region aka Kuzbass for implementation of carbon control tools. The materials cover the period from 2015 to 2020.

Kuzbass is a typical resource region that relies heavily upon fuel and metallurgical in-

\footnotetext{
Authors' note.
}

dustries. In 2020, $30 \%$ of the tax revenues of the local budget came from coal mining $(20.9 \%)$ and metallurgical enterprises $(8.6 \%)$. In fact, Kuzbass is the largest exporter of coal to the CIS and non-CIS countries. Up to $70 \%$ or more of Russian annual coal exports come from Kuzbass. The energy sector is carbon intensive, which makes the formation of climate agenda one of the priorities of the regional environmental policy (Concept, 2020). Despite the environmental risks and the prospects of carbon and technological control, the Kuzbass-2035 Strategy defines the local fuel, energy, chemistry, and metallurgy as the main drivers of economic growth. However, these industries will have to lower their environmental impact if they want to grow and develop (Strategy, 2020).

\section{Methods}

The present research features a strategic environmental assessment of the prospects for the socio-economic development of Kuzbass. The analysis includes an inventory of GHG emitted by the local enterprises and an assessment of the capacity of the local ecosystems. The analysis relies on the assessment of the potential for transition to a carbon control.

\section{Discussion}

According to the inventory report on the structure of GHG emissions, Energy sector is responsible for the largest share $-72.3 \%$, Industrial Processes and Product Utilization - for $16.95 \%$, and Agriculture - for $8.9 \%$. Compared to 1990, the sectors of Energy, Industrial Processes, and Product Utilization increased their share by an average of 2-4\%, while Agriculture declined by $3.5 \%$. The assessment of the absorptive capacity of Kuzbass ecosystems rendered an important result: while forests occupy about $60 \%$ of the territory, and national parks - about $16 \%$, the absorption capacity does not exceed $13 \%$. Table 1 illustrates the inventory of GHG in Kuzbass and shows that the carbon intensity of the local economy has been decreasing over the past five years. However, the decrease results not from the decrease in GHG emissions, but from the higher GRP growth rates. 
Table 1. Carbon intensity of Kuzbass economy

\begin{tabular}{|l|c|c|c|c|c|c|}
\hline \multicolumn{1}{|c|}{ Indicator } & 1990 & 2015 & 2016 & 2017 & 2018 & 2019 \\
\hline $\begin{array}{l}\text { GRP, in current prices, million ru- } \\
\text { bles* }\end{array}$ & - & 843345.4 & 903348.9 & 1097861.0 & 1266424.5 & 1110415.1 \\
\hline $\begin{array}{l}\text { GHG emissions, thousand tons of } \\
\mathrm{CO}_{2} \text {-eq. }\end{array}$ & 193142.1 & 133013.6 & 133127.8 & 135408.3 & 134207.7 & 134598.3 \\
\hline $\begin{array}{l}\text { GHG emissions, thousand tons of } \\
\mathrm{CO}_{2} \text {-eq.including absorption }\end{array}$ & - & 121904.6 & 121920.9 & 123953.7 & 122672.9 & 122968 \\
\hline $\begin{array}{l}\text { Carbon intensity of the economy, t/ } \\
\text { mln rubles GRP }\end{array}$ & - & 0.158 & 0.147 & 0.123 & 0.105 & 0.121 \\
\hline
\end{tabular}

*Source: Internet portal of Kemerovostat (Kemerovo Statistic Service). Access mode: https://kemerovostat.gks.ru/folder/38633 (accessed 15 May 2021)

The analysis also reveals the following local specific: $61.7 \%$ of the structure of emissions is methane emissions. As for the emissions dynamics, the volume of methane emissions from stationary sources increased by 305,000 tons (39 \%) in 2019, compared to $2009^{2}$. During the same period, other harmful emissions from stationary sources in Kuzbass increased by only $2.4 \%$. For comparison, Energy sector lowered its $\mathrm{CO}_{2}$ emissions by $28.6 \%$ and doubled fugitive methane emissions, compared to 1990. Obviously, an increase in underground coal mining, which is the most environmentally friendly method, will increase the volume of fugitive methane emissions. This method will also make it difficult to assess the export of GHG emissions, should a cross-border carbon tax be introduced. It is cross-border carbon control that creates significant risks for the development of the coal industry as a whole.

Kuzbass has exhausted almost all options for reducing GHG emissions to $70 \%$ compared to the 1990. According to the inventory of GHG gases and the assessment of the absorptive capacity of ecosystems, Kuzbass has been increasing emissions over the past five years at a very slow pace. However, if compared to the 1990 level, they have already decreased by $69.49 \%$. This means that the quantitative objective can be achieved in the current period without much effort, even in the absence of car-

\footnotetext{
2 Source: data from the Territorial Body of the Federal State Statistics Service for the Kemerovo Region and the South Siberian Interregional Directorate of Rosprirodnadzor (Federal Service for Supervision of Natural Resource Usage)
}

bon control, considering that methane is not on the list of marker substances for coal mining and processing enterprises. The situation may change dramatically if the quantitative objective for GHG emissions is tightened and reaches $60-65 \%$ of 1990 .

However, to assess the potential reduction of GHG emissions in the foreseeable future, one needs a comprehensive analysis of their retrospective dynamics (Porfirev et al., 2020a). An analysis of the best practices in the field of low-carbon development suggests that the market is already forcing some Russian companies to act in accordance with the current decarbonization (Blam et al., 2020). As a result, large Russian energy and metallurgical companies that are headquartered in Kuzbass are busy developing strategies to reduce their GHG emissions. Metallurgic giants EVRAZ and RUSAL ${ }^{3}$ were fast enough to publish their climate strategies and adjusted environmental targets early in 2021. They intend to achieve environmental goals and modernize production by using the best available technologies (EVRAZ Strategy, 2021). For example, the climate agenda of EVRAZ in Kuzbass includes measures to reduce GHG emissions in its metallurgical sector to $20 \%$ per ton of steel by 2030 . In fact, the company has developed a one billion rubles investment program that will allow it to reduce methane emissions by $75 \%$ in its coal mining sector.

\footnotetext{
3 Assess mode: https://news.rambler.ru/ecology/43252743kompaniya-rusal-predstavila-prioritety-ekologicheskoypolitiki-na-5-let/ (accessed 20 May 2021)
} 
The absorption capacity of reclaimed ecosystems, naturally restored disturbed lands, and new green belts needed a separate assessment. The present research includes preliminary estimates of the volume of potential absorption. The analysis is based on the following presumption: in 5-7 years, the annual replenishment of the forest resources by 5,000 hectares provides the absorbing capacity of about 35,000 t/ $\mathrm{CO}_{2}$-eq., excluding previous forest plantations. In 2020-2025, absorption will actually be provided by the trees planted in 2013-2020. The authors believe that forest management should be based on models that take into account economic and legal relations, the current state of forest lands, the species and age composition, operational efficiency, forest fires, etc. (Pyzhev et al., 2019).

The analysis is based on strategic documents on climate agenda and carbon control tools, effective «green» cases implemented by individual companies, and materials for assessing the carbon intensity of the Kuzbass economy. It suggests several scenarios for the development of the region through 2050 during climate adaptation period. In fact, a lot of publications substantiate various options and scenarios for Russia's transition to low-carbon development in different periods. Bashmakov and Myshak (2014) performed a comparative analysis of forecasts of GHG emissions and scenarios in Energy sector for the period up to 2050-2060. They analyzed more than 70 scenarios developed by Russian scientists and classified them into five groups. Their comparison of these scenarios of the dynamics of GHG emissions in the Energy sector of Russia through 2060 showed a large zone of uncertainty. In fact, the range of emission values predicted for 2050 varies from 220 million tons of $\mathrm{CO}_{2}$-eq. to 6,500 million tons of $\mathrm{CO}_{2}$-eq., depending on macroeconomic assumptions, intensity of environmental policy measures etc.

Among the numerous approaches, the scenarios proposed by the experts from the Institute of Economic Forecasting of the Russian Academy of Sciences seem to offer the optimal key principles and criteria for assessing the potential of low-carbon development of Kuzbass. The experts described three scenarios: basic, reasonable, and aggressive (Porfirev et al., 2020a).

Applied to Kuzbass economy, these lowcarbon development scenarios will be the following:

1. Basic. In the period through 2030-2035, Kuzbass economy will develop in accordance with its «genetic code» and the milestones defined in the Kuzbass-2035 Strategy. Some structural and technological changes will appear as the market will affect the behavior of large coal and metallurgical companies. Energy sector will see no significant changes: coal will remain the main type of fuel; methane emissions will be partially utilized for heat and energy production; utilities will be gasified in accordance with national projects. In this scenario, GHG emissions can be stabilized through climate projects, e. g. extensive forest plantations. Carbon polygons and farms will increase the absorptive capacity of the local ecosystems. They will keep emissions at $70 \%$ of 1990. As for the risks, most organizations will receive integrated environmental permits for 7 years in the conditions of a system of technological control that is absolutely «insensitive» to environmentalization processes.

2. Reasonable. More ambitious environmental objectives may result from the potential for climate adaptation of the regional economy, accumulated during the basic stage, the influence of the international market, and the requirements of national projects. The authors believe that all Kuzbass enterprises will manage even if the level reaches $60-65 \%$ after 2035. The main risk is that carbon control tools may not work during the basic stage. Even if the EU imposes a cross-border tax, it may not affect the pace of environmentalization because the main coal export is east-oriented, i. e. to countries with a more loyal climate control regime.

3. Aggressive. This scenario can take place if GHG control uses effective tools of the regulatory «guillotine» and a system of technological control based on the best available technologies. Without these working tools, any aggressive scenario to make Kuzbass economy carbon neutral will fail. The policy of its main partner, China, can also become an important 
stimulus. If Chinese economy passes the peak of carbon intensity in the 2030s and focuses on achieving carbon neutrality by 2050-2060, it can change the balance of interests at the international level. In this case, the forecast is $17 \%$ of the 1990 level (Porfirev et al., 2020a). Again, the current large-scale forestation projects in Kuzbass can play an important role. If the level of absorption is $30-35 \%$, it can improve the carbon balance.

\section{Conclusion}

The International Climate Agenda affects the development of environmental objectives for regions and individual companies. The carbon intensity makes products more competitive on the market and serves as a marker of the sustainability and efficiency of the economy.

During the period of climate adaptation, resource-type regions may risk their economy because their rates of structural and technological modernization are usually low and incentives from carbon control tools are weak.

To improve its carbon balance, Kuzbass should focus on creating conditions for increasing the absorption capacity of forest ecosystems; all stakeholders in the climate adaptation process should set up carbon polygons and farms on a voluntary basis.

\section{References}

Analytical report «Risks of the implementation of the Paris Climate Agreement for the economy and national security of Russia». Institute for Problems of Natural Monopolies. Moscow. 2016. P. 11. Available at: http://www.ipem.ru/files/files/other/doklad_riski_realizacii_parizhskogo_klimaticheskogo_soglasheniya_dlya_ekonomiki_i_nacionalnoy_bezopasnosti_rossii.pdf(accessed 15 May 2021)

Bashmakov, I.A., Myshak, A.D. (2014). Sravnenie prognozov vybrosov parnikovykh gazov v sektore «energetika» Rossii na 2010-2060 g. [Comparison of forecasts of greenhouse gas emissions in the Russian energy sector for 2010-2060], In Problemy prognozirovania [Forecasting problems], 4, 48-62.

Bobylev, S.N. (2020). Ustoichivoe razvitie: novoe videnie budushchego? [Sustainable development: a new vision of the future?], In Voprosy politicheskoi ekonomiki [Problems in Political Economy], 1(21), 67-83. DOI: 10.5281/zenodo.3753332

Blam, I. Yu., Kovalev, S. Yu. (2020). Nizkouglerodnyi trend v investitsionnoi politike: poisk effektivnykh adaptatsionnykh mekhanizmov [Low-carbon trend in investment policy: search for effective adaptation mechanisms], In ECO, 3, 160-176. DOI: 10.30680/ECO0131-7652-2020-3-160-176.

Decree of the President of the Russian Federation of November 4, 2020, No. 666: «On reducing greenhouse gas emissions». Available at: https://www.garant.ru/products/ipo/prime/doc/74756623/ (accessed 10 May 2021).

Decree of the President of the Russian Federation of February 8, 2021, No. 76: «On measures to implement the state scientific and technical policy in the field of environmental development of the Russian Federation and climate change». Available at: http://www.consultant.ru/document/cons_doc_LAW_376296/ (accessed 10 May 2021).

Draft Law «On limiting greenhouse gas emissions». Available at: https://sozd.duma.gov.ru/ bill/1116605-7 (accessed 10 May 2021).

Global Risk Report 2020. World Economic Forum. (2020)

Global Warming of $1.5^{\circ} \mathrm{C}$ : an IPCC Special Report on the Impacts of Global Warming of $1.5^{\circ} \mathrm{C}$ above Pre-Industrial Levels and Related Global Greenhouse Gas Emission Pathways, in the Context of Strengthening the Global Response to the Threat of Climate Change, Sustainable Development, and Efforts to Eradicate Poverty. Summary for Policymakers. - Formally Approved at the First Joint Session of Working Groups I, II and III of the IPCC and Accepted by the 48th Session of the IPCC. Incheon, Republic of Korea, 6 October 2018. 33 p.

ICAP. Kazakhstan ETS suspended until 2018. Available at: https://icapcarbonaction. com/ru/newsarchive/387-kazakhstan-ets-suspended-until-2018

Kulapin, A.I. (2019). Strategicheskoe razvitie TEK v svete prinyatiia Parizhskogo soglasheniiia po klimatu [Strategic development of the fuel and energy sector in the light of the adoption of the Paris Climate 
Agreement], In Energy policy, 3(141), 72-77. Available at: https://minenergo.gov.ru/node/16337 (accessed 10 May 2021).

Makarov, I.A., Stepanov, I.A. (2017). Carbon Regulation: Options and Challenges for Russia, In Moscow University Bulletin. Ser. 6. Economy, 6, 3-22.

On the approval of the Strategy for the socio-economic development of the Kemerovo region through 2035. Law of the Kemerovo Region of December 26, 2018, No. 122-OZ // Code. Available at: http://docs.cntd. ru/document/550305101 (accessed 18 February 2020).

Order of the Ministry of Natural Resources of Russia dated April 16, 2015, No 15-r: "On the approval of methodological recommendations for conducting a voluntary inventory of greenhouse gas emissions in the constituent entities of the Russian Federation». Available at: https://sudact.ru/law/rasporiazhenieminprirody-rossii-ot-16042015-n-15-r/metodicheskie-rekomendatsii-po-provedeniiu-dobrovolnoi/ (accessed 10 May 2021).

Order of the Ministry of Natural Resources of Russia (Ministry of Natural Resources and Environment of the Russian Federation) of June 30, 2015 No. 300: «On the approval of methodological instructions and guidelines for quantifying the volume of greenhouse gas emissions by organizations carrying out economic and other activities in the Russian Federation». Available at: https://www.garant.ru/products/ipo/prime/ doc/71183290/ (accessed 10 May 2021).

Order of the Ministry of Natural Resources and Environment of the Russian Federation of June 29, 2017, No. 330: "On Approval of Methodological Guidelines for Quantifying the Volume of Indirect Energy Emissions of Greenhouse Gases» (has not entered into force). Available at: https://www.garant.ru/products/ ipo/prime/doc/71660524/ (accessed 10 May 2021).

Order of the Government of the Kemerovo Region - Kuzbass of 08/31/2020, No. 574-r: «On Approval of the Concept of Environmental Policy of Kuzbass»

EVRAZ strategy for reducing greenhouse gas emissions. Available at: https://mstrok.ru/news/ ekologicheskaya-povestka-nesomnennyy-prioritet-dlya-kompanii-evraz-ozvuchil-chetyre (accessed 18 May 2021).

Paris Agreement, UN, 2015. Available at: http://unfccc.int/paris_agreement/items/9485.php

Porfirev, B.N., Shirov A. A., Semikashev V.V., Kolpakov A. Yu. (2020). Economic Risks in the Context of Policy Development with Low Greenhouse Gas Emissions in Russia, In Energy Policy, 5 (147), 93-103. DOI: 10.20542/0131-2227-2020-64-9-15-25

Porfirev, B.N., Shirov, A.A., Kolpakov, A. Yu. (2020). Low-Carbon Development Strategy: Prospects for the Economy, In World Economy and International Relations, 64, 9, 15-25(a). DOI: 10.20542/01312227-2020-64-9-15-25

Pyzhev, A.I., Zander, E.V. (2019). Modeling of the regional forest sector to improve economic and legal relations in forest management, In J. Sib. Fed. Univ. Humanit. Soc. Sci., 12(11), 2091-2096. DOI: 10.17516/1997-1370-0515.

World Bank. State and Trends of Carbon Pricing 2016, Washington, DC, 2016.

UNFCCC. INDCs as communicated by Parties. Available at: http://www4.unfecc.int/Submissions/ INDC/Submission\%20Pages/submissions.aspx 